\title{
Opłata od posiadania psów w miastach na prawach powiatu. Analiza badań empirycznych
}

Fees for having dogs in cities with poviat rights.

An analysis of an empirical research

Streszczenie. Przedmiotem opracowania jest analiza problematyki dotyczącej opłaty od posiadania psów w miastach na prawach powiatu w Polsce. Celem publikacji jest analiza poszczególnych rozwiązań, a także argumentów, które stały się czynnikiem decydującym w poszczególnych miastach do podjęcia bądź zaniechania ustanowienia stosownej uchwały dotyczącej wprowadzenia opłaty od posiadania psów. Autorki przeprowadziły badania we wszystkich miastach na prawach powiatu za pomocą ankiet składających się z 10 pytań.

Słowa kluczowe: opłata; pies; uchwała; opłata od posiadania psów; ankieta.

Abstract. The elaboration presents an analysis of issues concerning a charge in Polish cities with district rights for having a dog. The purpose of this publication is to analyse particular solutions as well as motives, which have become a deter- 
mining factor in individual cities, on whether to pass or not to pass an appropriate local laws introducing a fee for having a dog. The authors conducted their research in all cities with district rights in Poland. In that regard they used surveys consisting of 10 questions.

Keywords: fee; dog; local laws; fees for having dogs; questionnaire.

\section{Wprowadzenie}

Przedmiotem prowadzonych badań było zbadanie funkcjonowania opłaty od posiadania psów w miastach na prawach powiatu, które skorzystały z możliwości jej wprowadzenia na podstawie ustawy o podatkach i opłatach lokalnych ${ }^{1}$, oraz poznanie opinii miast na prawach powiatu, które z pobierania wyżej wspomnianej opłaty zrezygnowały. Badania są kontynuacją wcześniej prowadzonych badań na temat występowania opłaty od posiadania psów w miastach na prawach powiatu. Ustalono w nich krąg miast na prawach powiatu, których rady zdecydowały w stosownej uchwale o wprowadzeniu opłaty od posiadania psów. Ustalenie faktu, czy opłata w określonym mieście na prawach powiatu jest pobierana, możliwe było za pośrednictwem Biuletynu Informacji Publicznej. Badania zostały przeprowadzone za pomocą metody ankietowej - oddzielnie dla miast, które podjęły stosowną uchwałę w sprawie wprowadzenia opłaty od posiadania psów, oraz oddzielnie dla miast, które tej opłaty nie wprowadziły. Na tej podstawie zostało ustalone, że 17 miast na prawach powiatu wprowadziło opłatę od posiadania psów, co stanowi ok. 26\% wszystkich badanych miast, natomiast 49 miast na prawach powiatu nie podjęło stosownej uchwały mającej na celu wprowadzenie opłaty od posiadania psów, co stanowi ok. 74\% wszystkich badanych miast. Ogółem na 10 zadanych w ankiecie pytań, które zostały przesłane skarbnikom miast na prawach powiatu, odpowiedziały 33 miasta, w tym 7 miast, które podjęły uchwałę dotyczącą opłaty od posiadania psów, oraz 26 miast, które nie wprowadziły opłaty od posiadania psów.

Ustawa z dnia 12 stycznia 1991 r. o podatkach i opłatach lokalnych (tekst jedn. Dz.U. z 2016 r., poz. 716 ze zm.). 
Miasta na prawach powiatu powstały na mocy ustawy o samorządzie powiatowym z dnia 5 czerwca 1998 r. $^{2}$ Badany obszar obejmuje miasta znajdujące się na terenie całego kraju. Uzupełniająco należy wskazać, iż na podstawie art. 91 ustawy o samorządzie powiatowym prawa powiatu przysługiwały miastom, które z dniem 31 grudnia 1998 r. przestały być siedzibami wojewodów, chyba że na wniosek właściwej rady miejskiej odstąpiono od nadania miastu praw powiatu. Prawa powiatu przysługiwały miastom, które liczyły więcej niż 100000 mieszkańców, a także tym, którym nadano status miasta na prawach powiatu przy dokonywaniu pierwszego podziału administracyjnego kraju na powiaty. W Polsce obecnie jest 66 miast na prawach powiatu.

W tej płaszczyźnie należy zaznaczyć, iż od dnia 1 stycznia 2008 r. podatek od posiadania psów został zniesiony. Ustawodawca w ustawie o podatkach i opłatach lokalnych $\mathrm{w}$ art. 18a przewidział możliwość wprowadzenia fakultatywnej opłaty od posiadania psów przez radę gminy, którą pobiera się od osób fizycznych posiadających psy. Rada miasta może pobierać opłatę w drodze inkasa lub określić inkasentów i wysokość ich wynagrodzenia ${ }^{3}$. W powołanym artykule wskazane zostały osoby, od których nie pobiera się opłaty od posiadania psów. Są nimi:

1. członkowie personelu przedstawicielstw dyplomatycznych i urzędów konsularnych oraz inne osoby zrównane z nimi na podstawie ustaw, umów lub zwyczajów międzynarodowych, jeżeli nie są obywatelami polskimi i nie mają miejsca stałego pobytu na terytorium Rzeczypospolitej Polskiej - pod warunkiem wzajemności;

2. osoby zaliczane do znacznego stopnia niepełnosprawności w rozumieniu przepisów o rehabilitacji zawodowej i społecznej oraz zatrudnianiu osób niepełnosprawnych - z tytułu posiadania jednego psa;

3. osoby niepełnosprawne $\mathrm{w}$ rozumieniu przepisów ustawy $\mathrm{z}$ dnia 27 sierpnia 1997 r. o rehabilitacji zawodowej i społecznej oraz zatrudnianiu osób niepełnosprawnych - z tytułu posiadania psa asystującego;

2 Ustawa z dnia 5 czerwca 1998 r. o samorządzie powiatowym (tekst jedn. Dz.U. z 2016 r. poz. 814 ze zm.).

3 A. Borodo, Polskie prawo finansowe, Toruń 2014, s. 174. 
4. osoby w wieku powyżej 65 lat prowadzące samodzielnie gospodarstwo domowe $-\mathrm{z}$ tytułu posiadania jednego psa;

5. podatnicy podatku rolnego od gospodarstw rolnych $-\mathrm{z}$ tytułu posiadania nie więcej niż dwóch psów.

\section{Przedmiot i cel badania empirycznego}

Towarzysząca człowiekowi ciekawość skutkowała prowadzeniem przez niego licznych obserwacji i prób interpretacji otaczającego świata. Ludzka aktywność stała się potężną siłą napędową rozwoju nauki. Z biegiem czasu proste obserwacje zostały zastąpione bardziej zaawansowanymi metodami badawczymi, a badania uzyskały przymiotnik „naukowych”. Badania społeczne to nic innego jak kompleksowy proces, który ma na celu zapewnienie obiektywnego i wyczerpującego poznania danego problemu. Mianem procesu określamy schemat działania, podejmowany w celu uzyskania wiedzy, który trwa bezgranicznie ${ }^{4}$. Jak wskazuje S. Nowak, badania to ciąg jednostkowych czy zbiorowych czynności, który otwiera sformułowanie problemu, a który następnie zmierza do rozwiązania tego problemu ${ }^{5}$. Przed podjęciem jakichkolwiek działań ważne jest, aby badacz jasno określił przedmiot oraz cel planowanych badań. Przedmiotem badań są obiekty, pomiędzy którymi zachodzą określone relacje. Przedmioty te są istniejące i posiadają również charakterystyczne cechy. Na uniwersum nauk społecznych składają się: ludzie, zbiorowości złożone z ludzi, obiekty, do których ludzie się odnoszą, i obiekty tworzone lub przekształcane przez ludzi ${ }^{6}$. Badaniom można przypisać wiele celów. W nauce najczęściej wskazuje się na trzy z nich. Prowadzący badania badacz pragnie zwrócić uwagę opinii publicznej na jakiś temat lub przybliżyć innym określone zagadnienie. Takie podejście najczęściej spotykane jest w sytuacji, kiedy dana problematyka nie jest częstym tematem publikacji czy badań prowadzonych przez innych badaczy. Wiele osób prowadzących

\footnotetext{
4 Ch. Frankfort-Nachmiast, D. Nachmiast, Metody badawcze w naukach społecznych, Poznań 2001, s. 36.

S. Nowak, Metodologia badań społecznych, Warszawa 1985, s. 21.

J. Karpiński, Wprowadzenie do metodologii nauk społecznych, Warszawa 2006, s. 43.
} 
badania za cel stawia sobie opis danej sytuacji lub wydarzenia, który jest pierwszym ze wskazywanych celów. Obserwację naukową, kolejny z wymienionych, cechuje dokładność i staranność, co skutkuje tym, że opis naukowy jest bardziej trafny niż opis zwykły. Warto jednak wskazać, że badacz najczęściej nie poprzestaje na opisie, a dąży do wyjaśnienia, dlaczego istnieją zaobserwowane prawidłowości i jakie są ich konsekwencje. Wyżej wspomniane wyjaśnianie jest właśnie trzecim najchętniej wymienianym przez autorów celem badań. Wymienione cele są jedynie celami najczęściej wskazywanymi i należy zastanowić się nad zasadnością ich wyodrębniania. W praktyce prowadzenie badań wiąże się z wypełnieniem wszystkich trzech wymienionych.

Celem opisywanych tutaj badań jest stwierdzenie, czy wyżej wspomniana opłata generuje koszty, dochody, bądź czy związane z wprowadzeniem opłaty od posiadania psów dochody wystarczają jedynie na pokrycie kosztów, które stwarza jej pobór. Kolejnym celem jest określenie charakteru opłaty od posiadania psów.

\section{Problem badawczy i hipotezy badawcze}

Badanie, aby mogło uzyskać przymiot „naukowego”, na każdym etapie musi spełniać określone warunki. Jednym z wymogów jest ustalenie problemu badawczego, który w nauce definiowany jest jako sformułowane pytanie czy mniej lub bardziej uporządkowany zbiór pytań ${ }^{7}$, który staje się bodźcem do prowadzenia badań. Na wybór problemu i jego określenie wpływ mają dwa rodzaje czynników: społeczne i teoretyczne ${ }^{8}$.

Za problem badawczy przeprowadzonych badań miast na prawach powiatu posiadających opłatę od posiadania psów należy uznać odpowiedzi na poszczególne pytania:

1. Kiedy opłata od posiadania psów została wprowadzona?

2. Jaką funkcją opłaty od posiadania psów kierowano się, wprowadzając opłatę?

\footnotetext{
S. Nowak, Metodologia badań..., s. 26.

B. Szacka, Wprowadzenie do socjologii, Warszawa 2003, s. 43.
} 
3. Czy i jakie działania zostały podjęte w celu uaktywnienia posiadaczy psów, którzy nie uiszczają opłaty?

4. Jaka liczba osób w ubiegłym roku uiściła w poszczególnych miastach opłaty od posiadania psów?

5. Czy wprowadzane są dodatkowe zwolnienia, np. dla właścicieli psów pochodzących ze schroniska?

6. Na jakim poziomie kształtuje się wysokość opłaty od posiadania psów w poszczególnych miastach na prawach powiatu?

7. Jaki dominuje pogląd na temat wprowadzenia opłaty od posiadania psów na poziomie maksymalnym?

8. Czy opłata od posiadania psów powinna być jednolicie ustalona dla wszystkich zainteresowanych?

9. Czy rozważana jest rezygnacja z pobierania opłaty od posiadania psów?

10. Czy dobrym rozwiązaniem jest przekształcenie podatku od posiadania psów w fakultatywną opłatę? Dlaczego?

Za problem badawczy przeprowadzonych badań miast na prawach powiatu niepobierających opłaty od posiadania psów należy uznać odpowiedzi na poszczególne pytania:

1. Czy opłata funkcjonowała w mieście na prawie powiatu?

2. Dlaczego opłata od posiadania psów została zniesiona? / Dlaczego opłata od posiadania psów nie została wprowadzona?

3. Jaką rolę spełnia przede wszystkim opłata od posiadania psów?

4. Czy w najbliższym czasie będzie podejmowana próba wprowadzenia opłaty od posiadania psów?

5. Czy dodatkowe zwolnienia, np. dla właścicieli psów pochodzących ze schroniska, są dobrym rozwiązaniem?

6. Jaka liczba osób musiałaby uiszczać opłatę, aby została ona wprowadzona?

7. Na jakim poziomie musiałaby minimalnie kształtować się wysokość opłaty od posiadania psów, aby została wprowadzona?

8. Jakie działania zostały wprowadzone w mieście po wprowadzeniu opłaty od posiadania psów? / Jakie działania zostałyby podjęte po wprowadzeniu opłaty od posiadania psów? 
9. Czy opłata od posiadania psów zostałaby wprowadzona, gdyby została jednolicie ustalona dla wszystkich zainteresowanych?

10. Czy dobrym rozwiązaniem jest przekształcenie podatku od posiadania psów w fakultatywną opłatę? Dlaczego?

Kolejnym z wymogów stawianych przed badaczem jest ustalenie hipotez roboczych, które w nauce nazywane są prowizorycznymi odpowiedziami do zweryfikowania w toku prowadzonych badań ${ }^{9}$. Jeżeli stworzona hipoteza ulegnie odrzuceniu, to należy skonstruować nową. Obligatoryjność sformułowania hipotez roboczych staje jednak pod znakiem zapytania. Zdaniem S. Nowaka, element ten nie jest niezbędny w trakcie prowadzenia badań.

Sformułowano następujące hipotezy robocze dotyczące miast na prawach powiatu posiadających opłatę od posiadania psów, o których prawdziwości lub fałszywości przekonano się w wyniku tego badania. Opłata od posiadania psów została wprowadzona w miastach na prawach powiatu najczęściej w latach 2008-2009. Większość miast na prawach powiatu pobiera opłatę od posiadania psów. Podstawową funkcją opłaty jest funkcja fiskalna. Żadne działania nie są podejmowane w celu uaktywnienia osób, które opłaty nie uiszczają. Powyżej 60 osób w każdym $\mathrm{z}$ miast na prawach powiatu w ubiegłym roku uiściło opłatę. Dodatkowe zwolnienia z opłaty są chętnie stosowane. Wysokość opłaty od posiadania psów kształtuje się w większości miast na poziomie maksymalnym. Przekształcenie podatku w fakultatywną opłatę jest dobrym rozwiązaniem.

Hipotezy robocze badań dotyczących miast na prawach powiatu, które nie posiadają opłaty od posiadania psów, stanowią, co następuje. Podstawową funkcją opłaty jest funkcja fiskalna. Większość miast na prawach powiatu nie zamierza podejmować w najbliższym czasie działań mających na celu wprowadzenie opłaty od posiadania psów, nawet jeśli jej wysokość miałaby być ustalona się na poziomie maksymalnym. Liczne zwolnienia z opłaty od posiadania psów są dobrym rozwiązaniem. Żadne działania nie zostały podjęte w miastach na prawach powiatu po wprowadzeniu opłaty od posiadania psów. Żadne działania nie zostałyby podjęte

$9 \quad$ Z. Ziembiński, Wykłady socjologii dla prawników i administratywistów, Warszawa 1990, s. 118. 
również po jej wprowadzeniu. Przekształcenie podatku od posiadania psów w fakultatywną opłatę jest dobrym rozwiązaniem.

\section{Metodologia i technika badań}

Metodologią nazywamy naukę humanistyczną o metodach badania stosowanych przez badaczy, która traktuje ich czynności jako racjonalne ${ }^{10}$. Terminem metody w nauce oznacza się typowe i powtarzalne sposoby zbierania, analizy i interpretacji danych empirycznych, służące do uzyskania maksymalnie zasadnych odpowiedzi na pytania, które dotyczą problemu badawczego ${ }^{11}$. Zastosowanie określonej metody ma na celu poznanie prawdy i usystematyzowanie twierdzeń, ponieważ wiedza nieugruntowana i nieusystematyzowana nie posiada wartości. Wybór metody nie podlega pełnej dowolności ze strony prowadzącego badania. Zdarza się, że przedmiot badań narzuca w pewnym stopniu wybór sposobu badania. Nie można zapominać o sformułowanych wcześniej celach, których osiągnięcie zostało założone przez badacza. Wybór powinien być podyktowany tym, aby zastosowana metoda w jak najwyższym stopniu zapewniała zasadność twierdzeń, które w wyniku jej zastosowania zostaną sformułowane. W przeprowadzonych badaniach zastosowano metodę wywiadu socjologicznego. Pojęcie metody łączy się z terminem techniki badań. Według J. Gniteckiego technika badań to celowy i racjonalny sposób postępowania badawczego odwołujący się do twierdzeń i teorii, który pozbawiony jest założeń ${ }^{12}$. Instrument, który służy zastosowaniu konkretnej techniki badań, to narzędzie badawcze. W przedstawianych badaniach narzędziem stał się kwestionariusz ankiety. Metoda ankiety umożliwia uzyskanie dużej ilości materiału poprzez wypełnienie przez respondentów zestawów pytań, które na ogół składają się z pytań zamkniętych i otwartych. Ankieta wysłana drogą mailową pozwoliła na zebranie danych bez uczestnictwa ankieterów, co skutkuje obniżeniem błędu stronniczości

\footnotetext{
J. Karpiński, Wprowadzenie do..., s. 11.

S. Nowak, Metodologia badań..., s. 46.

J. Gnitecki, Wprowadzenie do metod badań w naukach pedagogicznych, Poznań 2006, s. 107.
} 
w przeprowadzonych badaniach. Zaletą jest również to, iż uzyskano odpowiedzi od miast na prawach powiatów, które są rozproszone na obszarze całego kraju. Przeprowadzenie osobistych wywiadów wiązałoby się nie tylko z kosztami, ale i długim terminem zbierania danych. Ponadto kwestionariusz ankiety gwarantuje respondentom pełną anonimowość, która skutkowała uzyskaniem licznych odpowiedzi na pytanie otwarte. W celu uzyskania jak najbardziej zasadnych wyników wykorzystano również obserwację oraz analizę aktów prawnych znajdujących się w Biuletynie Informacji Publicznej.

Kwestionariusze składały się z 10 pytań, spośród których 9 pytań stanowiło pytania zamknięte opatrzone $\mathrm{w}$ tzw. kafeterię, a więc zestaw gotowych odpowiedzi. Ostatnie było pytaniem otwartym. Ankiety zostały przesłane skarbnikom miast na prawach powiatu drogą mailową wraz z prośbą o ich wypełnienie. Ponowna prośba o wypełnienie ankiety, jeśli odpowiedź nie została uzyskana, była wysyłana po upływie 14 dni. W razie braku odpowiedzi po upływie kolejnych 14 dni do skarbników miast na prawach powiatu wysyłano kwestionariusze po raz trzeci.

\section{Wyniki badań $w$ miastach na prawach powiatu pobierających opłatę od posiadania psów}

W ankiecie skierowanej do miast na prawach powiatu, które wprowadziły opłatę od posiadania psów, do respondentów zostało skierowane pytanie, kiedy została wprowadzona opłata od posiadania psów. Respondenci mieli możliwość wyboru jednej spośród czterech możliwych odpowiedzi określającej lata, w których wskazana opłata została wprowadzona: lata 2008-2009, 2010-2011, 2012-2013 czy też 2014-2016. Z uzyskanych odpowiedzi niewątpliwie wynika, że najwięcej opłat zostało wprowadzonych po zniesieniu podatku od posiadania psów, czyli w latach 20082009 - zaznaczyło takową odpowiedź pięć miast, natomiast dwa miasta w latach 2012-2013.

Kolejne pytanie miało na celu wskazanie, czym kierowały się miasta wprowadzając opłatę od posiadania psów. W odpowiedziach respondenci 
mieli do wyboru funkcję fiskalną opłaty, funkcję wychowawczą opłaty, funkcję organizacyjną opłaty bądź też żadną z powyższych. Trzy miasta udzieliły odpowiedzi, że kierowały się funkcją wychowawczą opłaty, dwa miasta funkcją fiskalną opłaty, jedno funkcją organizacyjną opłaty, a jedno wskazało, że nie kierowało się żadną z powyżej wymienionych odpowiedzi.

W pytaniu trzecim zapytano respondentów, czy i jakie działania podejmuje dane miasto na prawach powiatu w celu uaktywnienia posiadaczy psów, którzy nie uiszczają opłaty. Podobnie jak w poprzednich pytaniach była możliwość wyboru spośród czterech odpowiedzi, które sygnalizowały następujące działania: postępowanie egzekucyjne, informowanie mieszkańców o konieczności uiszczania opłaty, brak zamiaru podejmowania bądź niepodejmowanie żadnych działań. Ostatnią możliwą odpowiedzią były inne działania, gdzie należało podać, jakie. Dwa miasta zaznaczyły, iż podejmują postępowanie egzekucyjne, jedno opowiedziało się za informowaniem o konieczności uiszczania opłaty przez mieszkańców, również jedno z miast stwierdziło, że nie podejmuje bądź nie zamierza podejmować w związku z tym żadnych działań. Dwa miasta wskazały na dwa działania, jakie podejmują - jest to zarówno postępowanie egzekucyjne, jak i informowanie o konieczności uiszczania opłaty. Otrzymano również ustosunkowanie się do wskazanych odpowiedzi - „organ podatkowy wysyła wezwania w celu złożenia wyjaśnienia w sprawie posiadania psa/psów między innymi na podstawie zawiadomień Straży Miejskiej, która przesyła dane o osobach, które są upominane lub ukarane za wykroczenie mające związek z posiadaniem psa”, które wskazywałoby, że dane miasto podejmuje zarówno postępowanie egzekucyjne, jak i informowanie o konieczności uiszczania opłaty.

Kolejne pytanie miało na celu ustalenie liczby osób, które uiściły opłatę od posiadania psów w danym mieście na prawach powiatu. Zakres osób, które dokonały opłaty w możliwych wariantach odpowiedzi, kształtował się następująco: od 1 do 20, od 21 do 40, od 41 do 60, powyżej 60 . Sześciu respondentów udzieliło odpowiedzi, że opłatę w ich mieście uiściło ponad 60 osób, natomiast jeden z respondentów odpowiedział, że opłaty dokonało od 1 do 20 mieszkańców. 
Kwestią zasadniczą było również ustalenie odpowiedzi na pytanie, czy miasta na prawach powiatu, które wprowadziły opłatę od posiadania psów, przewidziały także dodatkowe zwolnienia, np. dla osób które są właścicielami psów pochodzących ze schroniska. Respondenci mieli możliwość wyboru jednej spośród czterech następujących odpowiedzi: nie, ponieważ nie należy różnicować osób uiszczających opłatę; nie, ponieważ zwolnienia znacznie zmniejszą dochody; tak, zachęcamy tym samym do adopcji psów ze schroniska; tak, dodatkowe zwolnienia nie zmniejszają w znacznym stopniu dochodów uzyskanych z niniejszej opłaty. Sześciu udzielających odpowiedzi wskazało, że tak, ponieważ miasto zachęca tym samym do adopcji psów ze schroniska, natomiast jedno z miast nie zaznaczyło żadnej odpowiedzi, podkreślając, że rada miasta zwalnia z opłaty osoby w wieku powyżej 65 lat bez warunku prowadzenia samodzielnego gospodarstwa domowego.

Zapytano również, na jakim poziomie kształtuje się wysokość opłaty od posiadania psów w badanych miastach na prawach powiatu. Spośród możliwych wariantów odpowiedzi zakreślających wysokość opłaty w danym mieście: do 60 zł rocznie od jednego psa, od 61 zł do 90 zł rocznie od jednego psa, od 91 zł do 110 zł rocznie od jednego psa, od 111 zł do 120,05 zł (maksymalna stawka) rocznie od jednego psa, zdecydowana większość - sześć miast odpowiedziało, że opłata roczna od jednego psa wynosi do 60 zł, w tym jedno miasto dodatkowo podkreśliło, że wynosi ona 50 zł rocznie. Natomiast tylko jedno z miast zaznaczyło, że wysokość opłaty wynosi zazwyczaj od 61 zł do 90 zł rocznie od jednego psa.

Następne pytanie dotyczyło opinii poszczególnych respondentów z miast na prawach powiatu w kwestii wprowadzenia opłaty od posiadania psów na poziomie maksymalnym. Należało wybrać jedną z czterech zaproponowanych odpowiedzi: wprowadzenie opłaty od posiadania psów na poziomie maksymalnym nie jest dobrym rozwiązaniem, ponieważ kwota maksymalna jest zbyt wysoka w stosunku do możliwości finansowych dużej grupy społeczeństwa, a zatem jej wprowadzenie może skutkować mniejszą skutecznością poboru opłaty. Kolejna odpowiedź brzmiała następująco: wprowadzenie opłaty od posiadania psów na poziomie maksymalnym jest kwestią kontrowersyjną, jednak zabieg ten pozwala na znale- 
zienie źródła dochodów, które są w stanie polepszyć sytuację budżetową miasta. Przedostatnia odpowiedź wskazywała, że wprowadzenie opłaty od posiadania psów na poziomie maksymalnym nie ma racji bytu - stanie się to „uciążliwością” dla osób, które do tej pory uiszczały opłatę od posiadania psów. Natomiast ostatnia odpowiedź podkreślała, że opłata od posiadania psów na poziomie maksymalnym jest w stanie wygenerować wpływy do budżetu jedynie, jeśli zostanie stworzona baza informacji o posiadanych psach, dzięki której pobór opłaty będzie bardziej efektywny. Zdecydowana większość osób udzielających odpowiedzi na zadane pytanie (sześciu respondentów) uważa, że wprowadzenie opłaty od posiadania psów na poziomie maksymalnym nie jest dobrym rozwiązaniem. Kwota maksymalna jest zbyt wysoka w stosunku do możliwości finansowych dużej grupy społeczeństwa. Jej wprowadzenie może skutkować mniejszą skutecznością poboru opłaty. Jeden z respondentów wskazał dodatkowo, poza przywołaną wyżej odpowiedzią, że wprowadzenie opłaty od posiadania psów na poziomie maksymalnym nie ma racji bytu, gdyż stanie się to „uciążliwością” dla osób, które do tej pory uiszczały opłatę od posiadania psów.

Jedno z pytań w przeprowadzonej ankiecie miało również na celu ustalenie, czy opłata od posiadania psów powinna być jednolicie ustalona dla wszystkich zainteresowanych. Respondenci mieli do wyboru następujące warianty odpowiedzi: tak, jest to sprawiedliwe rozwiązanie; tak, wówczas większa liczba gmin zdecydowałaby się na wprowadzenie tej opłaty; nie, każda gmina powinna mieć możliwość decydowania o wysokości niniejszej opłaty; nie, jednolita opłata nie zwiększy liczby osób, które ją uiszczają. Zdecydowana większość zaznaczyła odpowiedź, która podkreślała, że opłata od posiadania psów nie powinna być jednolicie ustalona dla wszystkich zainteresowanych, ponieważ każda gmina powinna mieć możliwość decydowania o wysokości niniejszej opłaty - odpowiedziało tak pięciu respondentów. Jedno z miast wskazało, że opłata nie powinna być jednolicie ustalona dla wszystkich zainteresowanych, ponieważ jednolita opłata nie zwiększy liczby osób, które ją uiszczają. Tylko jedno z miast opowiedziało się za ujednoliceniem opłaty od posiadania psów, ponieważ ich zdaniem jest to sprawiedliwe rozwiązanie. 
Ostatnie z pytań, w którym respondenci mieli możliwość wyboru odpowiedzi, dotyczyło zamiaru rezygnacji z opłaty od posiadania psów. Możliwe były do wyboru następujące warianty: nie, ponieważ opłata przynosi oczekiwany zysk; nie, ponieważ opłata na przestrzeni lat jej obowiązywania dobrze funkcjonuje; tak, ponieważ opłata nie przynosi oczekiwanych zysków; tak, ponieważ zdecydowana większość osób mimo obowiązku nie uiszcza opłaty. Jedno z miast nie zaznaczyło żadnej z podanych odpowiedzi, natomiast zdecydowana większość (pięciu respondentów) stwierdziło, że nie chcą rezygnować z opłaty od posiadania psów w ich mieście, ponieważ dobrze funkcjonuje. Tylko jedno z miast chce zrezygnować z opłaty, gdyż zdecydowana większość osób mimo obowiązku nie uiszcza opłaty.

Celem pytania otwartego było ustalenie, czy zdaniem respondentów dobrym rozwiązaniem jest przekształcenie podatku od posiadania psów w opłatę fakultatywną. Swoją odpowiedź należało krótko uzasadnić. Odpowiedzi były następujące: „opłata fakultatywna nie jest dobrym rozwiązaniem. Obywatele w Polsce uważają, że jeżeli nie trzeba wpłacać na pewien cel, tego nie robią. Z uwagi na fakt, iż pośrednio wpływy z tej opłaty zasilają schroniska dla bezdomnych zwierząt, zasadne jest obligatoryjne pobieranie tej opłaty przez gminy, które tą opłatę wprowadzą. Większość schronisk w Polsce to organizacje pożytku publicznego, które fakultatywnie mogą być wspomaganie poprzez przekazanie 1\% podatku dochodowego od osób fizycznych. Co prawda można się zastanawiać, dlaczego ustawodawca nie wprowadził podobnej opłaty, np. dla kotów, co wydaje się pewną formą dyskryminacji dla osób, które posiadają psa”. Pojawiły się mniej rozbudowane odpowiedzi podkreślające, że dobrym rozwiązaniem jest przekształcenie podatku od posiadania psów w opłatę fakultatywną, „ponieważ zwiększa to samorządność gmin”. Spotkano się również z argumentem, iż „opłata od posiadania psów winna być obowiązkowa w całym kraju. Byłoby to sprawiedliwe rozwiązanie. O jej wysokości natomiast powinna decydować rada gminy. Istnieje znaczne zróżnicowanie zdolności dochodowej ludności w poszczególnych regionach kraju”. Respondenci podkreślali, że „w wielu gminach koszty poboru obligatoryjnego podatku od posiadania psów przekraczały wpływy z tego 
tytułu. W obecnym stanie prawnym to gmina decyduje, czy wprowadzić na jej terenie opłatę od posiadania psów, a w sytuacji, gdy opłata ta nie spełnia założonych celów (przede wszystkim fiskalnych), może z tej opłaty zrezygnować”. Podkreślano też, że dzięki takiemu rozwiązaniu „gminy mogą same decydować o przedsiębiorstwie”. Dwa z badanych miast udzieliły krótkiej odpowiedzi tak bądź nie, bez uzasadnienia.

\section{Wyniki badań w miastach na prawach powiatu nie pobierających opłaty od posiadania psów}

Pierwsze pytanie miało na celu ustalenie, czy opłata w danym mieście na prawach powiatu nigdy nie funkcjonowała, czy też została wprowadzona, ale z jej pobierania zrezygnowano. Respondenci mieli do wyboru dwie alternatywne odpowiedzi. Zdecydowana większość miast po zniesieniu podatku od posiadania psów nie skorzystała z możliwości wprowadzenia fakultatywnej opłaty od posiadania psów, a więc opłata w tych miastach nigdy nie funkcjonowała - takiej odpowiedzi udzieliło 19 miast na prawach powiatu. Pięciu respondentów stwierdziło, że zrezygnowało z poprzednio wprowadzonej opłaty od posiadania psów.

Drugie pytanie zmierzało do ustalenia, dlaczego w badanych miastach na prawach powiatu opłata od posiadania psów nigdy nie została wprowadzona bądź dlaczego w perspektywie dalszych działań podjęto decyzję o jej zniesieniu. Respondenci mieli możliwość wyboru czterech możliwych wariantów odpowiedzi, które wskazywały, że opłata jedynie generuje koszty, bądź że jest nieznaczna liczba osób, która uiszcza niniejszą opłatę lub ze względu na znaczną liczbę gmin, w których nie funkcjonuje niniejsza opłata. Pojawiła się również możliwość udzielenia innej odpowiedzi. Siedem miast na prawach powiatu stwierdziło, że opłata generuje jedynie koszty. Cztery miasta powołały się na fakt, że jest nieznaczna liczba osób, która uiszcza niniejszą opłatę. Jeden respondent udzielił odpowiedzi, podkreślając, że przyczyną jest znaczną liczba innych gmin, w których nie funkcjonuje opłata od posiadania psów. 
Cztery miasta wskazały na dwie przyczyny - mianowicie do braku funkcjonowania niniejszej opłaty przyczynia się fakt, że opłata generuje jedynie koszty, jak również to, że jest nieznaczna liczba osób, które uiszczają niniejszą opłatę. Jedno z miast na prawach powiatu wskazało, że powodem jest zarówno generowanie kosztów przez tą opłatę, jak i czynnik niefunkcjonowania opłaty w znacznej liczbie gmin. Miasta, który udzielały własnej odpowiedzi, powoływały się na to, iż Rada Miasta nie podjęła stosownej uchwały, bądź Rada Miasta nie podjęła stosownej uchwały dotyczącej stawek, lub że opodatkowanie posiadania psów w Polsce jest absurdem prawnym, jak również, iż przywiązywano wagę do „negatywnych opinii mieszkańców”. Można było spotkać się również z odpowiedzią, w której podkreślano, że „podsumowując koszty poboru i obsługi związanej z opłatą od posiadania psów oraz zbyt niskie wpływy z opłaty i trudny do realizacji system kontroli, uznano wprowadzenie opłaty za bezzasadne”. Podobne uzasadnienie wskazywały inne miasta, stwierdzając, że „analiza relacji kosztów do dochodów z tego tytułu była głównym powodem rezygnacji z pobierania jej na terenie gminy”. Zdarzały się również bardzo dokładne i opisowe odpowiedzi uzasadniające rezygnację z opłaty od posiadania psów: „w uzasadnieniu uchwały jako powód podano, iż pobieranie opłaty przez znaczną część posiadaczy psów uważane jest za niesprawiedliwe i nie zachęca do opieki nad psami. Liczne zwolnienia $\mathrm{z}$ opłaty zarówno ustawowe, jak i wynikające $\mathrm{z}$ uchwały, powodują trudności $\mathrm{z}$ jej egzekwowaniem. Znaczne koszty windykacji dodatkowo umniejszają jej niewysokie wpływy”. Jedno z miast zaznaczyło zaproponowaną odpowiedź, że jest nieznaczna liczba osób, które uiszczają niniejszą opłatę, dodatkowo podkreślając „uchylanie się od obowiązku płacenia tej opłaty. Podnoszono problematykę rejestracji innych zwierząt domowych, np. kotów. Sprawa dotyczy równouprawnienia $\mathrm{w}$ podejściu do pobieranych opłat. Powoływano się również na stosunkowo niewielki dochód, jaki był uzyskiwany z opłaty od posiadania psów w skali całego budżetu, problemy i koszty związane z windykacją tych należności oraz chęć Prezydenta Miasta do zniesienia dodatkowych obciążeń dla podatników. 
W kolejnym pytaniu zapytano respondentów, jaką rolę ich zdaniem spełnia przede wszystkim opłata od posiadania psów. Zaproponowano trzy funkcje: fiskalną, organizacyjną oraz wychowawczą. Podobnie jak w poprzednim pytaniu istniała również możliwość podania innej własnej odpowiedzi. Zdecydowana większość - trzynastu respondentów stwierdziła, że opłata od posiadania psów spełnia przede wszystkim funkcję fiskalną. Żadne z udzielających na pytanie odpowiedzi miast nie wskazało na funkcję organizacyjną, natomiast dwa stwierdziły, że jest to funkcja wychowawcza. Jedno z miast na prawach powiatu uważa, że niniejsza opłata pełni funkcję zarówno fiskalną, jak i wychowawczą, a jedno, że organizacyjną i wychowawczą. Pięciu respondentów udzieliło własnej odpowiedzi podkreślając, iż ta opłata nie spełnia żadnej funkcji, ponieważ nie została wprowadzona przez dane miasto. Można było spotkać się również ze stwierdzeniem, że „nie spełnia żadnej z wyżej wymienionych ról”, jedno z miast uzasadniło to stwierdzeniem, że „nie przynosi znaczących dochodów, spotyka się ze sprzeciwem mieszkańców i zwiększa bezdomność psów”. Inne miasta również podkreślały, że np. mają do czynienia ze zjawiskiem, w którym występuje jedynie więcej bezdomnych psów. Trzech respondentów nie udzieliło odpowiedzi na zadane pytanie.

Następne pytanie miało na celu ustalenie, czy badane miasta na prawach powiatu mają zamiar podjąć stosowną uchwałę w najbliższym czasie, aby wprowadzić opłatę od posiadania psów. Respondenci mieli do wyboru następujące odpowiedzi: nie, ponieważ nie zaistniała taka potrzeba; nie, ponieważ jest niewiele miast na prawach powiatu, które korzystają z tej możliwości; tak, opłata może zwiększyć dochód (funkcja fiskalna); tak, zdecyduje się na jej wprowadzenie znaczna liczba innych gmin. Dwadzieścia miast na prawach powiatu wskazało, że nie podejmie stosownej uchwały celem wprowadzenia opłaty od posiadania psów, ponieważ nie zaistniała taka potrzeba. Dwóch respondentów odpowiedziało, że ich miasto nie zamierza wprowadzić tej opłaty, powołując się na fakt, że jest niewiele miast na prawach powiatu, które korzystają z tej możliwości. Niektóre osoby udzielające odpowiedzi ustosunkowały się pisemnie do zadanego pytania, wskazując na brak stosownej wiedzy do udzielenia 
odpowiedzi na zadane pytanie, gdyż „taką decyzje podejmują radni”. Stwierdzono również, że próba wprowadzenia opłaty od posiadania psów zostałaby podjęta, gdyby zaistniały okoliczności powodujące powszechność jej poboru. W okresie jej pobierania w zasadzie opłatę tę uiszczały jedynie osoby poczuwające się do tego obowiązku. Duża liczba osób posiadających psy nie przyznawała się do bycia ich właścicielem podczas próby ustalenia właściciela celem opodatkowania. Tymczasem pobieranie opłaty tylko od osób, które dobrowolnie ją regulują, jest niesprawiedliwe względem pozostałych zobowiązanych i przeczy zachowaniu podstawowych podatkowych zasad konstytucyjnych, tj. równości wobec prawa i powszechności opodatkowania, a także zaufania obywateli do organów władzy publicznej. Ponadto, przepisy w zakresie tej opłaty uniemożliwiają organowi podatkowemu zachowanie tych zasad. W przypadku innych zobowiązań publicznoprawnych (np. podatków lokalnych) podmioty dysponujące wiedzą na temat ewentualnych przedmiotów opodatkowania są zobligowane na mocy przepisów ustawowych do systematycznego i terminowego przekazywania organom podatkowym tych informacji. W zakresie opłaty od posiadania psów żadne przepisy powszechnie obowiązujące nie ułatwiają organowi podatkowemu pozyskania informacji o ich posiadaczach i nie przesądzają o sposobie kontroli posiadania psów. Nie istnieje też żadna powszechna ewidencja właścicieli psów. Niewyegzekwowanie opłaty od wszystkich osób posiadających psy rodzi niezadowolenie i poczucie niesprawiedliwości wobec osób dobrowolnie wywiązujących się z tego obowiązku. Wszelkie próby wyegzekwowania opłaty od wszystkich osób zobowiązanych do jej uiszczenia są skazane na niepowodzenie.

Kolejne pytanie skierowane do respondentów dotyczyło opinii na temat dodatkowych zwolnień od uiszczania opłaty od posiadania psów. Były możliwe cztery alternatywne odpowiedzi: nie, ponieważ nie należy różnicować osób uiszczających opłatę; nie, ponieważ zwolnienia znacznie zmniejszą dochody; tak, zachęcamy tym samym do adopcji psów ze schroniska; tak, dodatkowe zwolnienia nie zmniejszają w znacznym stopniu dochodów uzyskanych z niniejszej opłaty. Czternaście miast stwierdziło, że dodatkowe zwolnienia są dobrym rozwiązaniem, ponieważ za- 
chęcają do adopcji psów ze schroniska. Siedmiu respondentów wskazało, że nie jest to dobre rozwiązanie, ponieważ nie należy różnicować osób uiszczających opłatę. Żadne z miast udzielających odpowiedzi nie powołało się na wpływ opłaty na ewentualny dochód miasta. Pozostali respondenci nie udzielili odpowiedzi, czasami podając przyczynę, iż to pytanie nie dotyczy ich miasta. Podkreślano także, że „trudno ustosunkować się do tego pytania, gdyż w związku z niewprowadzeniem tej opłaty przez Radę Miasta oraz brakiem inicjatywy ze strony radnych, nikt nie analizuje przepisów w tym zakresie”.

Prowadząc badania dotyczące opłaty od posiadania psów, postanowiono zapytać również o to, jaka liczba osób musiałaby uiszczać opłatę od posiadania psów, aby miasta zdecydowały się na jej wprowadzenie. Odpowiedzi brzmiały następująco: powyżej 20, powyżej 50, powyżej 80 , powyżej 100, trudno powiedzieć. Jedynie trzech respondentów wskazało, że liczba osób uiszczających opłatę musiałaby oscylować powyżej 100 . Reszta miast nie udzieliła odpowiedzi na to pytanie bądź jak zdecydowana większość stwierdziła, że trudno powiedzieć. Jedno z miast wskazało, że musiałaby być to „liczba około 10000 osób”, inne, że „nie były prowadzone analizy w tym zakresie”. Pojawiła się także odpowiedź brzmiąca następująco: „moim zdaniem, Miasto XYZ zdecydowałoby się na wprowadzenie opłaty od posiadania psów bez względu na konkretną ilość osób, gdyż każda dodatkowa kwota dochodu w budżecie miasta jest ważna”. Ważną rolę mogłaby odegrać powszechna ewidencja właścicieli psów, udostępniana z mocy prawa organom podatkowym. Na podstawie danych ewidencji można byłoby opodatkować osoby niewywiązujące się z obowiązku opłacania tej opłaty. Istotą rolę odegrałoby uproszczenie procedur podatkowych w zakresie tej opłaty i zmniejszenie kosztów ewentualnego jej wyegzekwowania. Obecnie koszty te wynoszą minimalnie 29,90 zł (wszczęcie postępowania w drodze postanowienia, wysyłanego za zwrotnym potwierdzeniem odbioru, wyznaczenie terminu na zapoznanie się z materiałem dowodowym, koszty doręczenia decyzji określającej tę opłatę i koszty upomnienia). Część osób posiadająca psy utrzymuje się ze świadczeń z pomocy społecznej i wyegzekwowanie opłaty jest bezskuteczne, przy czym organ podatkowy jest obciążany dodatkowo 
kosztami egzekucyjnymi. Być może wskazana byłaby zmiana przepisów polegająca, np. na niepobieraniu tej opłaty od osób (czy też zwolnieniu z opłaty osób), które na mocy odrębnych przepisów uprawnione są do świadczeń z pomocy społecznej lub korzystają z tych świadczeń. Wówczas nie uruchamiałoby się procedury podatkowej i egzekucyjnej. Tymczasem wprowadzenie na terenie danej gminy innych niż wymienione w ustawie zwolnień przedmiotowych jest w praktyce bardzo trudne. Każde zwolnienie przedmiotowe z podatku czy opłaty lokalnej w istocie sprowadza się do zwolnienia podmiotowego i zapisy uchwałowe w tej kwestii są podważane przez organ nadzoru, tj. Regionalną Izbę Obrachunkową.

Kolejne pytanie miało na celu ustalenie, na jakim poziomie musiałaby minimalnie kształtować się wysokość opłaty od posiadania psów, aby dane miasto zdecydowało się na jej wprowadzenie. Respondenci mieli do wyboru pięć alternatywnych odpowiedzi: do 50\% maksymalnej wysokości opłaty od posiadania psów obwieszczanej przez Ministra Finansów; od 51\% do 75\% maksymalnej wysokości opłaty od posiadania psów obwieszczanej przez Ministra Finansów; od 76\% do 99\% maksymalnej wysokości opłaty od posiadania psów obwieszczanej przez Ministra Finansów; na poziomie maksymalnym; bądź też żadna z powyższych. Maksymalna wysokość opłaty od posiadania psów obwieszczana przez Ministra Finansów wynosi w momencie prowadzonych badań 120,05 zł. Piętnastu respondentów odpowiedziało, że żadna z powyższych. Jedno z badanych miast stwierdziło, że opłata musiałaby wynosić do 50\% maksymalnej wysokości opłaty od posiadania psów obwieszczanej przez Ministra Finansów. Dwóch respondentów odpowiedziało, że od 51\% do 75\% maksymalnej wysokości opłaty od posiadania psów obwieszczanej przez Ministra Finansów, natomiast trzech udzielających odpowiedzi na pytanie wskazało, iż musiałaby być to stawka na poziomie maksymalnym. Pozostali nie udzielili odpowiedzi na to pytanie. Niektórzy wskazali, że „nie ma takich przeliczeń, bądź że nie rozważano zagadnienia w tych kryteriach, jak również, że nie były prowadzone analizy w tym zakresie”.

Zostało zadane również pytanie, którego celem było ustalenie, jakie działania zostały wprowadzone w mieście na prawach powiatu po wprowadzeniu opłaty od posiadania psów bądź też jakie działania podjęłoby 
dane miasto na prawach powiatu po wprowadzeniu opłaty od posiadania psów. Respondenci mieli możliwość wyboru następujących odpowiedzi: kosze na terenie miasta, które ułatwiają właścicielom utrzymanie porządku po psach; akcja reklamowa nakłaniająca właścicieli do utrzymania czystości po swoich czworonogach; inne; bądź żadna z powyższych. Czterech respondentów odpowiedziało, że zostały umieszczone kosze na terenie miasta, które ułatwiają właścicielom utrzymanie porządku po psach. Taka sama liczba respondentów stwierdziła, że zostały przeprowadzone akcje reklamowe nakłaniające właścicieli do utrzymania czystości po swoich czworonogach. Pięć miast wskazało na oba wyżej wskazane działania. Trzech respondentów podkreśliło, że podejmowało inne działania, natomiast jedno $\mathrm{z}$ miast odpowiedziało, że nie podejmowało żadnych z powyżej zaproponowanych działań. Pięciu respondentów udzielających odpowiedzi na pytanie stwierdziło, że podejmowali następujące działania: umieszczono kosze na terenie miasta, które ułatwiały właścicielom utrzymanie porządku po psach, prowadzono akcje reklamowe nakłaniające właścicieli do utrzymania czystości po swoich czworonogach, oraz inne. Niektóre z miast dookreśliły inne działania, jakie wówczas zostały podjęte - m.in. „darmowe szczepienie przeciwko wściekliźnie dla psów tych osób, które terminowo uiściły opłatę, wybieg dla psów, większa liczba wybiegów dla psów, specjalne pogramy”. Jedno z miast stwierdziło, że „trudno ustosunkować się do tego pytania. Z uwagi na brak inicjatywy ze strony radnych w zakresie wprowadzenia tej opłaty nie zastanawiano się nad koniecznymi działaniami”. Respondent, który odpowiedział, że żadne z powyższych działań nie zostało podjęte, uzasadniał to tym, iż „decyzje należą do radnych, na co zechcą przeznaczyć środki budżetowe”.

W następnym pytaniu podjęto próbę ustalenia, czy miasta udzielające odpowiedzi w ankiecie wprowadziłyby opłatę od posiadania psów, gdyby została ona jednolicie ustalona dla wszystkich zainteresowanych. Respondenci mieli do wyboru jedną spośród czterech alternatywnych odpowiedzi: tak, byłoby to sprawiedliwe rozwiązanie; tak, wówczas większa ilość gmin zdecydowałaby się na wprowadzenie tej opłaty; nie, każda gmina powinna mieć możliwość decydowania o wysokości niniejszej opłaty; nie, jednolita opłata nie zwiększy liczby osób, które ją uiszczają. Na to pytanie 
zdecydowana większość - trzynastu respondentów odpowiedziało, iż nie wprowadziłaby opłaty od posiadania psów, gdyby została ona jednolicie ustalona dla wszystkich zainteresowanych, ponieważ jednolita opłata nie zwiększy liczby osób, które ją uiszczają. Dziewięć miast stwierdziło, że każda gmina powinna mieć możliwość decydowania o wysokości niniejszej opłaty. Tylko jedno z miast udzielających odpowiedzi w ankiecie wskazało, że byłoby to sprawiedliwe rozwiązanie. Jedno z miast stwierdziło, iż „trudno ustosunkować się do pytania. Wszystko zależy od przepisów regulujących pobór tej daniny oraz od woli radnych”.

\section{Przekształcenie podatku od posiadania psów w fakultatywną opłatę}

Ostatnie pytanie polegało na udzieleniu pisemnej odpowiedzi - należało ustosunkować się do tego, czy zdaniem osób wypełniających ankietę dobrym rozwiązaniem jest przekształcenie podatku od posiadania psów w opłatę fakultatywną oraz uzasadnić swoją odpowiedź. W wyniku przeprowadzonych badań uzyskano następujące opinie:

1. „Bardzo dobre rozwiązanie. Opłatę można, ale nie trzeba wprowadzić, a z podatku nie można zrezygnować”.

2. „Począwszy od dnia 1 stycznia 2008 r. ustawodawca zastąpił obligatoryjny podatek od posiadania psów fakultatywnym świadczeniem na rzecz gminy - opłatą od posiadania psów. Rada Miasta nie podjęła stosownej uchwały w tej kwestii, ponieważ koszty związane z obsługą opłaty od posiadania psów (pobór i egzekucja) byłyby niewspółmierne wyższe od osiąganych wpływów z tego tytułu”.

3. „Dobrym rozwiązaniem jest przekształcenie podatku od posiadania psów w opłatę fakultatywną. Ze względów ekonomicznych niezasadnym jest wprowadzanie tej opłaty w sytuacji, gdy koszty jej wyegzekwowania są niewspółmiernie wysokie w porównaniu do uzyskiwanych dochodów".

4. „Tak, to dobre rozwiązanie. Każda gmina powinna sama decydować o tym, czy na jej obszarze ma obowiązywać taka opłata, czy też nie. Gmina ma wówczas możliwość podjęcia racjonalnej decyzji w opar- 
ciu o rachunek ekonomiczny, gdyż niezasadnym byłoby wprowadzenie opłaty, której koszt pobierania oraz ewentualnej jej egzekucji byłby wyższy od wpływów z tytułu takiej opłaty”.

5. „Daje możliwość wyboru, nie narzuca obowiązku podatkowego”.

6. „Ustawą z dnia 7 grudnia 2006 r. o zmianie ustawy o podatkach i opłatach lokalnych oraz o zmianie niektórych innych ustaw (Dz.U. Nr 249, poz. 1828) w miejsce dotychczas funkcjonującego podatku od posiadania psów wprowadzono opłatę od posiadania psów. Od 1 stycznia 2008 r. danina publiczna związana z posiadaniem psów nie ma charakteru obligatoryjnego. Zatem rada miasta (rada gminy) może (ale nie musi, jak w przypadku podatku) wprowadzić do obowiązującego na terenie miasta systemu podatków i opłat lokalnych - opłatę od posiadania psów. Do końca 2006 r. rada gminy miała obowiązek wprowadzenia na swoim terenie podatku od posiadania psów. Jej swoboda ograniczała się jedynie do określania wysokości stawek podatku, oczywiście w granicach stawek maksymalnych. Skutkowało to dużym zróżnicowaniem stawek w poszczególnych gminach (od stawki 1 zł w gminach, które nie do końca chciały obciążać swoich mieszkańców tego rodzaju daniną - do stawki maksymalnej, w gminach które maksymalizowały wpływy podatkowe). Przekształcenie podatku od posiadania psów (obligatoryjnej daniny) w opłatę od posiadania psów (fakultatywna danina) umożliwiło rezygnację z tej daniny przez gminy, które nie chciały obciążać swoich mieszkańców tego rodzaju daniną lub gdy koszty jej poboru były równoważne z wpływami (lub czasami nawet niższe). Gmina Miasta z ww. powodów zrezygnowała z opłaty od posiadania psów. Było to możliwe tylko dlatego, że opłata od posiadania psów ma charakter fakultatywny".

7. „Podatek od posiadania psów był rodzajem należności publicznoprawnej, który stanowił rodzaj absurdu prawnego funkcjonującego w Polsce. Pies nie jest dobrem luksusowym, żeby go opodatkowywać. Pamiętać przy tym należy, że podatek od posiadania psów był podatkiem majątkowym podobnie jak np. podatek od nieruchomości”. 
8. „Takie rozwiązanie jest uzasadnione. Obowiązujący stan prawny w tej kwestii umożliwia gminom decydowanie o zakresie wprowadzonych obciążeń podatkowych dla mieszkańców gminy i jest to dobre rozwiązanie dla gmin”.

9. „Tak, każda gmina powinna mieć możliwość decydowania, czy wprowadzić opłatę od posiadania psów”.

10. „Tak, gdyż opłata jest fakultatywna i może być wprowadzona, a nie musi”.

11. „Tak. O wprowadzeniu opłaty od posiadania psów na terenie danej gminy decyduje rada gminy. W sytuacji, gdy koszty poboru ww. opłaty zdecydowanie przekraczają wpływy do budżetu gminy z tego tytułu, gminy nie muszą pobierać takiej opłaty”.

12. „Tak. Przekształcenie podatku w fakultatywną opłatę od posiadania psów daje możliwość wyboru wprowadzenia opłaty przez radę gminy stosownie do potrzeb i warunków danej gminy".

13. „Tak, pozwala to bowiem gminom samodzielnie decydować, czy wprowadzenie opłaty na jej terenie jest uzasadnione (np. ekonomicznie, organizacyjnie)”.

14. „Tak, gdyż opłata jest fakultatywna i może być wprowadzona, a nie musi”.

15. „Tak. Gmina ma możliwość sama decydować, czy wprowadzić opłatę od posiadania psów, czy nie”.

16. „Tak, to było dobre rozwiązanie. Podatek od posiadania psów był nieakceptowalny przez społeczność lokalną (często pytano, dlaczego jest podatek od psów, a nie ma podatku od kota, konia czy innego zwierzęcia). Nie wszyscy właściciele psów chcieli dobrowolnie dokonywać płatności tego podatku. Często dochodziło do sporów między podatnikami, a organem podatkowym, w szczególności gdy wszczęte było postępowanie egzekucyjne. Ponadto udowodnienie, kto jest podatnikiem tego podatku, było trudne, z uwagi na brak jakiejkolwiek ewidencji właścicieli psów. Zdarzało się, że koszty ustalenia wysokości podatku i jego poboru przewyższały kwotę podatku, co było nieekonomiczne z punktu finansów publicznych”. 
17. „Tak. Zwiększa to autonomię gmin w kreowaniu własnej polityki fiskalnej i budżetu oraz pośrednio polityki związanej z ilością psów na terenie gminy".

18. „Tak. Pozostawia wybór gminom”.

19. „Tak, ponieważ daje możliwość Radzie Gminy zadecydowania o wysokości oraz o konieczności wprowadzenia tej opłaty”.

20. „Trudno powiedzieć, bo zarówno forma podatku, jak i opłaty, nie jest formą doskonałą. Uważam, że trzeba byłoby na początku wprowadzić konieczność rejestracji obowiązkowej psa, a dopiero potem konieczność opłacania zobowiązania. W obecnym stanie prawnym gminy nie mają możliwości ani oszacowania ilości wpływów, ani też nie mają możliwości przeprowadzenia skutecznej egzekucji takiego zobowiązania”.

21. „Raczej nie. Jeśli opłata byłaby wprowadzona, ale opłacana nieobowiązkowo (jeśli dobrze rozumiem pytanie), to podatnicy „nieprzymuszeni” przepisami prawa, korzystaliby z możliwości jej niepłacenia”.

22. „Nie. Gminy nie posiadają skutecznych narzędzi do egzekucji obowiązku zgłaszania posiadania psa”.

23. „Nie. Tego typu opłaty nie powinny mieć charakteru fakultatywnego”. Jak łatwo zauważyć, zdecydowana większość respondentów udzieliła pozywanej odpowiedzi na zadane pytanie, uzasadniając swoją odpowiedź w różny sposób. Niektórzy wskazali tylko, że jest to dobre rozwiązanie, nie podając uzasadnienia.

\section{Podsumowanie}

W konkluzji tych rozważań należy podkreślić, iż na 66 miast na prawach powiatu zaledwie ok. $26 \%$ z nich zdecydowało się podjąć stosowną uchwałę w celu wprowadzenia i utrzymania opłaty od posiadania psów (17 miast). Natomiast pozostałe 49 miast - ok. $74 \%$ - po zniesieniu podatku od posiadania psów nie zdecydowało się na wprowadzenie stosownej uchwały bądź z niej zrezygnowało. Ogółem na 10 zadanych w ankiecie pytań, które zostały przesłane skarbnikom miast na prawach powiatu, odpowiedziały 33 miasta, w tym 7 miast, które podjęło uchwałę dotyczącą 
opłaty od posiadania psów, oraz 26 miast, które nie wprowadziło opłaty od posiadania psów. Pozostałe miasta nie udzieliły odpowiedzi, pomimo podjęcia trzech prób nawiązania kontaktu ze skarbnikami tych miast.

Nie ulega wątpliwości, iż opłata od posiadania psów ma swoich zarówno zwolenników, jak i przeciwników z całym wachlarzem argumentów za i przeciw, jednakże wyniki przeprowadzonych badań bezpośrednio wskazały, że zdecydowana większość miast nie widzi uzasadnienia dla wprowadzenia takiej opłaty na terenie swoich miast. Odnosząc się do problematyki opłaty od posiadania psów, stosunkowo duża grupa respondentów wskazała, że zmiana podatku na fakultatywną opłatę jest dobrym rozwiązaniem, ponieważ pozostawia głos decydujący miastom, a także możliwość indywidualnego rozważenia, czy jej wprowadzenie jest konieczne.

\section{Bibliografia:}

Borodo A., Polskie prawo finansowe, Wydawnictwo Dom Organizatora, Toruń 2014.

Frankfort-Nachmiast Ch., Nachmiast D., Metody badawcze w naukach społecznych, Zysk i S-ka Wydawnictwo s.c., Poznań 2001.

Gnitecki J., Wprowadzenie do metod badań w naukach pedagogicznych, Wydawnictwo WSPiA, Poznań 2006.

Karpiński J., Wprowadzenie do metodologii nauk społecznych, Wydawnictwo WSPiZ, Warszawa 2006.

Nowak S., Metodologia badań społecznych, Państwowe Wydawnictwo Naukowe, Warszawa 1985.

Szacka B., Wprowadzenie do socjologii, Oficyna Naukowa, Warszawa 2003.

Ziembiński Z., Wykłady socjologii dla prawników i administratywistów, Wydawnictwo Przemiany, Warszawa 1990. 